\title{
Ginsenoside Rg1 as an Effective Regulator of Mesenchymal Stem Cells
}

\author{
Fang He ${ }^{1,2 * t}$, Changyin $\mathrm{Yu}^{3 * t}$, Tao $\mathrm{Liu}^{3 * t}$ and Huilin $\mathrm{Jia}^{4}$ \\ ${ }^{1}$ Key Laboratory of Cell Engineering of Guizhou Province, The Affiliated Hospital of Zunyi Medical University, Zunyi, China, \\ ${ }^{2}$ Department of Oral and Maxillofacial Surgery, University Hospital of Tübingen, Tübingen, Germany, ${ }^{3}$ Department of \\ Neurology, The Affiliated Hospital of Zunyi Medical University, Zunyi, China, ${ }^{4}$ School of Stomatology, Xi'an Medical \\ University, Xi'an, China
}

OPEN ACCESS

Edited by: Vincent Kam Wai, Macau University of Science and Technology, Macau

Reviewed by: Patrick Ying Kit Yue, Hong Kong Baptist University,

Hong Kong

Qiang Wu,

Macau University of Science and Technology, Macau

*Correspondence: Fang $\mathrm{He}$

hfwyyx@yeah.net

Changyin Yu

ycynerve@163.com

Tao Liu

Itcells@163.com

${ }^{\dagger}$ These authors share first authorship

Specialty section: This article was submitted to Ethnopharmacology, a section of the journal Frontiers in Pharmacology

Received: 21 August 2019 Accepted: 03 December 2019

Published: 23 January 2020

Citation:

He F, Yu C, Liu T and Jia H (2020)

Ginsenoside Rg1 as an Effective Regulator of Mesenchymal Stem Cells.

Front. Pharmacol. 10:1565.

doi: 10.3389/fphar.2019.01565
Recently, breakthroughs have been made in the use of mesenchymal stem cells (MSCs) to treat various diseases. Several stem cell types have been authorized as drugs by the European Medicines Agency and the U.S. Food and Drug Administration. The Chinese official document "Notification of the management of stem cell clinical research (trial)" was also published in August 2015. Currently, China has approved 106 official stem cell clinical research filing agencies and 62 clinical research projects, which are mostly focused on MSC therapy. Hence, the optimization and development of stem cell drugs is imperative. During this process, maximizing MSC expansion, minimizing cell loss during MSC transplantation, improving the homing rate, precisely regulating the differentiation of MSCs, and reducing MSC senescence and apoptosis are major issues in MSC preclinical research. Similar to artemisinin extracted from the stems and leaves of Artemisia annua, ginsenoside Rg1 (Rg1) is purified from the root or stem of ginseng. In the human body, $\mathrm{Rg} 1$ regulates organ function, which is inseparable from its regulation of adult stem cells. Rg1 treatment may effectively regulate the proliferation, differentiation, senescence, and apoptosis of MSCs in different microenvironments in vitro or in vivo. In this review, we discuss recent advances in understanding the effect of Rg1 on MSCs and describe the issues that must be addressed and prospects regarding Rg1 regulation of MSCs in preclinical or clinical studies.

Keywords: ginsenoside Rg1, mesenchymal stem cells, proliferation, differentiation, apoptosis, senescence, preclinical study

\section{INTRODUCTION}

Mesenchymal stem cells (MSCs) are a class of multipotent adult stem cells that show both selfrenewal and high plasticity (Pittenger et al., 1999; He et al., 2018a; Wang et al., 2019). These cells can differentiate into adipocytes, osteoblasts, and chondrocytes in vitro and in vivo and secrete various anti-inflammatory cytokines and exosomes in different microenvironments (Chamberlain et al., 2007; Phinney and Pittenger, 2017). MSCs can be derived from many connective tissues and organ stroma, including bone marrow, Wharton's jelly of the umbilical cord, umbilical cord blood, adipose tissue, dental pulp, and periodontal tissues (Alison et al., 2000; Mastrolia et al., 2019). Meanwhile, 
these cells exhibit a fibroblastic morphology, adhere to a plastic surface when cultured in vitro, and share a common immunophenotype consisting of positive CD105, CD73, and CD90 expression and negative CD45, CD34, CD14, CD19, and HLA-DR expression (Wagers and Weissman, 2004). MSCs showing low immunogenicity are used for xenotransplantation to achieve immunomodulation and improve tissue regeneration (Jiang et al., 2002; He et al., 2018b). Thus, these cells are considered promising candidates in the management of several conditions, such as bone regeneration (Bruder et al., 1998), certain neurodegenerative disorders (Crigler et al., 2006), and graft-versus-host disease (Le Blanc et al., 2004).

Ginsenoside Rg1 (Rg1, molecular formula: $\mathrm{C}_{42} \mathrm{H}_{72} \mathrm{O}_{14}$, Figure 1, image from PubChem), which is derived from a hydride of a dammarane, is a monomer of a tetracyclic triterpenoid derivative. This molecule is mainly extracted and purified from the root or stem of ginseng (Leung and Wong, 2010; Xu et al., 2012). Ginsenosides are classified into 20(S)protopanaxadiol (PPD) and 20(S)-protopanaxatriol (PPT) according to the hydroxylation position on their core triterpene saponin structure. Unlike PPD-type ginsenosides (e.g., ginsenoside $\mathrm{Rb} 1$ with four sugars) that are slowly excreted into bile, Rg1 with two sugars belonging to the PPTtype ginsenosides is primarily eliminated via rapid hepatobiliary excretion. Therefore, the specific molecular structure of Rg1 is a

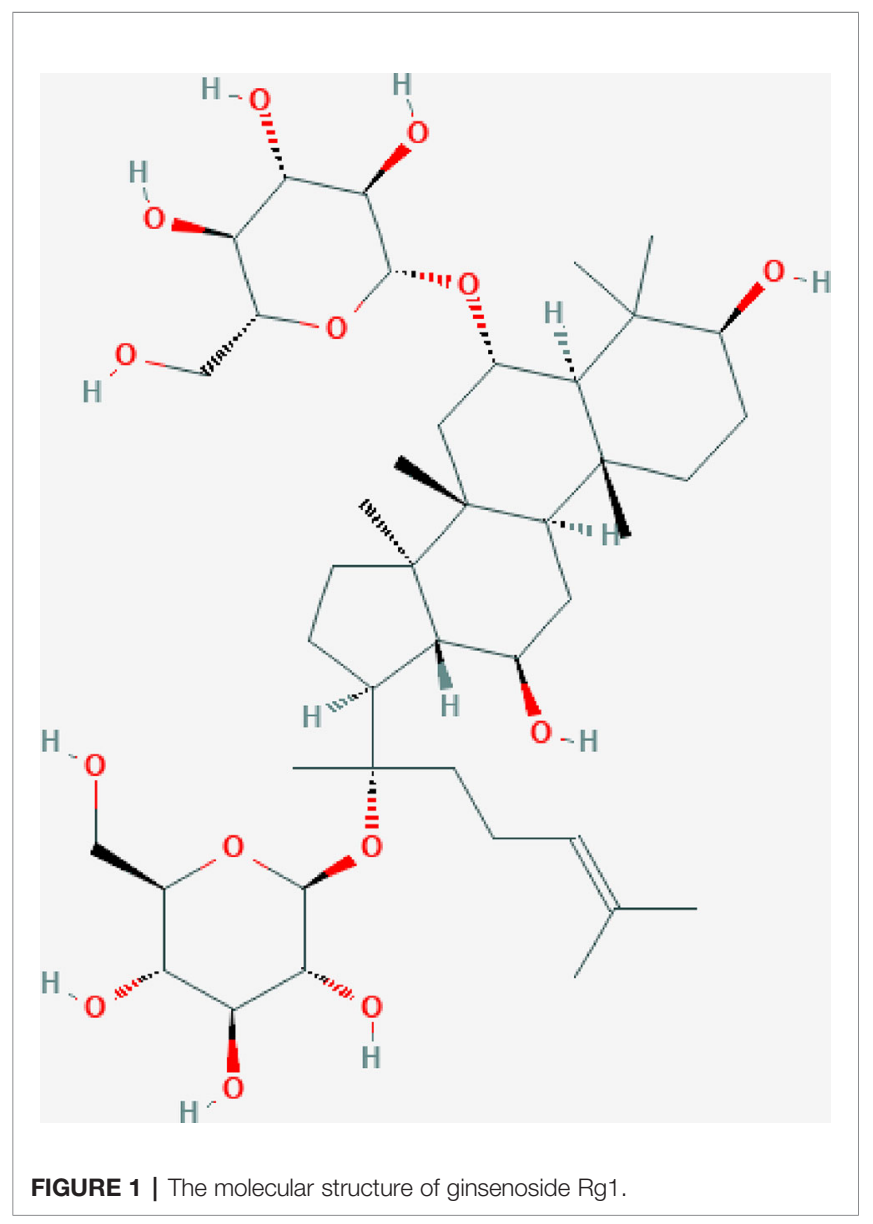

major determinant of $\operatorname{Rg} 1$ plasma pharmacokinetics and may also be a factor in drug interactions between Rg1 and its target molecules. In general, Rg1 can affect the nervous, cardiovascular, blood, and immune systems, showing various pharmacological activities (Lee et al., 1997; Fang and Limei, 2016). Rg1 has nutritional and protective effects on neurons and can reduce the apoptosis of nerve cells (Radad et al., 2004). Rg1 can be used to treat myocardial ischemia, long QT syndrome, and atherosclerosis by dilating coronary vessels, promote $\mathrm{K}+$ outflow, and inhibit the proliferation of vascular smooth muscle cells (Wei et al., 2007; Lee and Kim, 2014). The effect of Rg1 on the endocrine system is similar to that of steroid hormones; for instance, $\operatorname{Rg} 1$ can compete with dexamethasone to bind glucocorticoid receptors to promote the secretion function of cells, and it can be blocked by estrogen receptor antagonists (Chan et al., 2002). Rg1 can also improve nonspecific immunity in humans and promote the hematopoietic and immune function recovery of patients with bone marrow injury; thus, this molecule can be used to treat various immune and hematopoietic system diseases (Lee et al., 2004; Xu et al., 2012). Simultaneously, five clinical trials on the use of drugs containing Rg1 to treat vascular dementia, cognitive changes, Sjögren's syndrome, rheumatic diseases, and stroke, as well as a safety evaluation, have been registered on clinicaltrials.gov; three of these trials have completed recruitment, and the related results have been published; two have not yet completed subject recruitment (Sotaniemi et al., 1995; Ellis and Reddy, 2002; Scholey et al., 2010; Ossoukhova et al., 2015; Shin et al., 2016; Tian et al., 2016).

In recent years, the characteristics, functions, and therapeutic effects of MSCs and the pharmacological effects of Rg1 have been extensively studied (Zhan et al., 2014; Shyh-Chang and Ng, 2017; Jin et al., 2019). The effect and mechanism of $\operatorname{Rg} 1$ on the biological characteristics and functions of MSCs is becoming increasingly clear. Multiple studies have found that Rg1 regulates the proliferation, differentiation, aging, and apoptosis of MSCs and thus affects tissue repair in the body.

\section{OPTIMIZATION OF THE EFFECTIVE CONCENTRATION OF RG1}

Appropriate concentrations of $\operatorname{Rg} 1$ can effectively regulate the expression of functional proteins and the secretion of active cytokines in MSCs, and overdosages can cause toxicity to cells and tissues (Liu et al., 2005; Mohanan et al., 2018). Traditionally, the active ingredients in ginseng are believed to be good nutritional supplements for pregnant women and beneficial for fetal development (Tiran, 2003; Ong et al., 2005). Recent studies have found that some concentration of $\mathrm{Rg} 1$ may have embryotoxic effects (Liu et al., 2006; Mohammed et al., 2016). In studies using the whole embryo culture technique, culturing with $\operatorname{Rg} 1$ (62.4 mM for mice and $37.4 \mathrm{mM}$ for rats) for $48 \mathrm{~h}$ reduced the total embryo morphological score, which is based on the crown-rump length, head length, flexion scores, forelimb bud scores, and hindlimb bud scores. Furthermore, the development of the heart; neural tube; cerebral vesicles; otic, optic, and 
olfactory organs; branchial arch; maxilla; mandible; yolk sac vasculature; and allantois was also affected by increased concentrations of Rg1 (Liu et al., 2006). In contrast, a low concentration of Rg1 (62.5-10000 nM) may have a slight effect on chick cardiomyocytes and mouse D3 stem cells (Mohammed et al., 2016). Therefore, pregnant women should be cautious when using ginseng or ginsenoside Rg1 during the first three months of pregnancy. This molecule should be administered at low concentrations. Studies have also shown that $1,000 \mu \mathrm{g} / \mathrm{L} \mathrm{Rg} 1$ inhibits the proliferation of rat bone marrow MSCs (BMSCs) (Fu and Zheng, 2013), and Rg1 concentrations exceeding $100 \mathrm{~mol} / \mathrm{L}$ are cytotoxic to human periodontal ligament stem cells (hPDLSCs) (Yin et al., 2015). Therefore, systematic and comprehensive studies need to be performed to clarify the toxic effects of different concentrations of $\mathrm{Rg} 1$ on human MSCs. In addition, we evaluated and classified the effective, ineffective, and inhibitory properties of $\mathrm{Rg} 1$ on the proliferation of MSCs in vitro and summarized and analyzed the effects of different $\mathrm{Rg} 1$ concentrations, hoping to provide a reference for subsequent studies (Supporting Information 1).

\section{RG1 REGULATES THE PROLIFERATION AND DIFFERENTIATION OF MSCS}

Conventionally, MSCs are separated and purified by adhering to plastic and undergoing serial passaging in vitro to expand the primary cells (Bruder et al., 1997; Le Blanc and Ringden, 2007). For the MSC drug preparation process, the MSC proliferation rate must be increased and sufficient amounts of purified MSCs must be obtained (Ikada, 2006; Ikebe and Suzuki, 2014). Furthermore, enhancing the differentiation of MSCs into neurocyte cells, endothelial cells, or bone cells will contribute to the treatment of clinical diseases, such as neuronal disease, cardiovascular disease, and bone injury (Deans and Moseley, 2000). At present, studies have shown that Rg1 can positively regulate the proliferation of MSCs from various adult tissues (Table 1) and induce the directional differentiation of MSCs in different environments (Table 2, Figure 2).

Initially, bone marrow was used as the main source to isolate MSCs, and methods for harvesting BMSCs are highly invasive. The limited number and maximal life span of primary MSCs harvested from bone marrow is a major challenge in the clinical use of these cells (Jiang et al., 2002; Kern et al., 2006). In previous experiments, $\operatorname{Rg} 1$ could promote the proliferation of rat BMSCs by upregulating the expression of GATA1 and GATA2 and enhancing their binding to DNA (Wang et al., 2007). Reports have also shown that $10 \mu \mathrm{mol} / \mathrm{L} \mathrm{Rg1} \mathrm{can} \mathrm{promote} \mathrm{the} \mathrm{neuron-}$ specific enolase (NSE) expression of rat BMSCs in low-glucose Dulbecco's modified Eagle's medium (DMEM) with or without brain homogenates from rats with dementia; furthermore, this treatment prevented the brain homogenate (dementia rats) induced inhibition of neuronal differentiation and enhanced the differentiation of BMSCs into specific subpopulations of neuron-like cells that express nerve growth factor (NGF) mRNA (Zuo et al., 2007; Wu et al., 2011). Moreover, Rg1-
TABLE 1 | Ginsenoside Rg1 promotes MSC proliferation in vitro.

\begin{tabular}{|c|c|c|c|}
\hline Study & MSC source & Proliferation & Notes \\
\hline Dong et al. (2017) & $\begin{array}{l}\text { Mouse } \\
\text { adipose tissue }\end{array}$ & $\mathrm{MTT} \uparrow$ & $\begin{array}{l}\text { Cells during } \\
\text { isobutylmethylxanthine } \\
\text { neural induction }\end{array}$ \\
\hline Gu et al. (2016) & $\begin{array}{l}\text { Rat bone } \\
\text { marrow }\end{array}$ & EdU+ cells, CCK8 $\uparrow$ & \\
\hline Hu et al. (2016) & $\begin{array}{l}\text { Rat bone } \\
\text { marrow }\end{array}$ & $\mathrm{CCK} 8 \uparrow$ & Cells inhibited by $\mathrm{H}_{2} \mathrm{O}_{2}$ \\
\hline Liu et al. (2016) & $\begin{array}{l}\text { Human } \\
\text { umbilical cord } \\
\text { blood }\end{array}$ & $\begin{array}{l}\text { Colony-forming } \\
\text { unit of fibroblasts } \\
\text { (CFU-F), CCK8 } \uparrow\end{array}$ & $\begin{array}{l}\text { Cells inhibited by tert- } \\
\text { butyl hydroperoxide }\end{array}$ \\
\hline Xu et al. (2016) & $\begin{array}{l}\text { Human } \\
\text { adipose tissue }\end{array}$ & CCK8 $\uparrow$ & $\begin{array}{l}\text { Rg1 combined with } \\
\text { platelet-rich fibrin }\end{array}$ \\
\hline Xu et al. (2014) & $\begin{array}{l}\text { Human } \\
\text { adipose tissue }\end{array}$ & 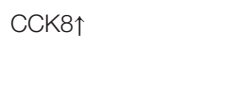 & $\begin{array}{l}\text { Cells during the } \\
\text { neurogenic } \\
\text { differentiation process }\end{array}$ \\
\hline Xu et al. (2015) & $\begin{array}{l}\text { Human } \\
\text { adipose tissue }\end{array}$ & CCK8 $\uparrow$ & $\begin{array}{l}\text { Cells during the } \\
\text { chondrogenic } \\
\text { induction process }\end{array}$ \\
\hline Yin et al. (2015) & $\begin{array}{l}\text { Human } \\
\text { periodontal } \\
\text { ligament }\end{array}$ & $\mathrm{MTT \uparrow}$ & $\begin{array}{l}\text { Cells during } \\
\text { dexamethasone } \\
\text { osteogenic induction }\end{array}$ \\
\hline Wang et al. (2014) & $\begin{array}{l}\text { Human dental } \\
\text { pulp }\end{array}$ & 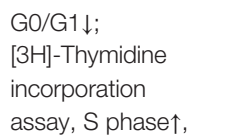 & \\
\hline Wang et al. (2012) & $\begin{array}{l}\text { Human dental } \\
\text { pulp }\end{array}$ & $\begin{array}{l}\text { G0/G1 } \downarrow \text {; } \\
\text { colony-forming } \\
\text { unit, MTT, S } \\
\text { phase } \uparrow\end{array}$ & \\
\hline Wang et al. (2007) & $\begin{array}{l}\text { Rat bone } \\
\text { marrow }\end{array}$ & $\begin{array}{l}\text { CFU-F, [3H]- } \\
\text { thymidine } \\
\text { incorporation } \\
\text { assay, GATA1 and } \\
\text { GATA2, binding } \\
\text { activities of GATA } \\
\text { and DNA, MTT } \uparrow\end{array}$ & \\
\hline Guo et al. (2017) & $\begin{array}{l}\text { Human bone } \\
\text { marrow }\end{array}$ & $\mathrm{MTT} \uparrow$ & $\begin{array}{l}\text { Rg1-loaded alginate- } \\
\text { chitosan microspheres }\end{array}$ \\
\hline $\begin{array}{l}\text { Fu and Zheng } \\
\text { (2013) }\end{array}$ & $\begin{array}{l}\text { Rat bone } \\
\text { marrow }\end{array}$ & $\mathrm{MTT} \uparrow$ & $\begin{array}{l}\text { Cells during hypoxia/ } \\
\text { serum deprivation }\end{array}$ \\
\hline
\end{tabular}

loaded alginate-chitosan microspheres were also shown to promote the proliferation and neuron-like differentiation of human BMSCs, increasing the expression of Nestin, NSE, and GFAP (Guo et al., 2017). This finding suggests that Rg1 can be used in the drug delivery/release studies and tissue engineering. However, no studies have explored the detailed mechanism by which $\operatorname{Rg} 1$ induces MSCs to differentiate into neuron-like cells with specific functions. For example, studies investigating the regulatory effects of $\mathrm{Rg} 1$ on BMSC differentiation into dopaminergic neurons or cholinergic neurons are needed. Therefore, clarification of the regulatory methods and related mechanisms of Rg1 may also be a "breakthrough point" for the treatment of neuronal disease such as Parkinson's disease and Alzheimer's disease and related neurological disorders in vivo.

Rg1 can also promote the differentiation of human BMSCs into endothelial cells. Experiments involving BMSCs and human umbilical vein endothelial cells cocultured in a transwell system showed that 20 to $80 \mu \mathrm{g} / \mathrm{ml}$ Rg1 gradually increased the mRNA and protein levels of mature endothelial cell-specific markers in 
TABLE 2 | Ginsenoside Rg1 promotes the directional differentiation of MSCs in vitro.

\begin{tabular}{|c|c|c|c|}
\hline Study & MSC source & Differentiation effects & Related mechanism \\
\hline Dong et al. (2017) & Mouse adipose tissue & $\begin{array}{l}\text { Neural differentiation induced by } \\
\text { isobutylmethylxanthine } \uparrow\end{array}$ & $\begin{array}{l}\text { Small C-terminal domain phosphatase } 1 \downarrow \text {; } \\
\text { miRNA-124, Nestin, } \beta \text {-tubulin III } \uparrow\end{array}$ \\
\hline Xu et al. (2014) & Human adipose tissue & $\begin{array}{l}\text { Neural differentiation in neural inductive conditioned } \\
\text { medium } \uparrow\end{array}$ & $\begin{array}{l}\text { NSE }^{a}, \text { microtubule-associated protein-2, growth-associated } \\
\text { protein-43, neural cell adhesion molecule, synapsin- } 1 \uparrow\end{array}$ \\
\hline Wu et al. (2011) & Rat bone marrow & $\begin{array}{l}\text { Neural differentiation inhibited by the brain } \\
\text { homogenate of a rat dementia model } \uparrow\end{array}$ & $\mathrm{NSE}^{a}$ positive cells $\uparrow$ \\
\hline Zuo et al. (2007) & Rat bone marrow & Neural differentiation $\uparrow$ & NSE ${ }^{a}$, nerve growth factor $\uparrow$ \\
\hline Guo et al. (2017) & Human bone marrow & $\begin{array}{l}\text { Rg1-loaded alginate-chitosan microspheres } \\
\text { promote neural differentiation }\end{array}$ & Nestin, NSE ${ }^{a}$, glial fibrillary acidic protein $\uparrow$ \\
\hline Gu et al. (2016) & Rat bone marrow & Osteogenic differentiation $\uparrow$ & $\begin{array}{l}\text { ALP }^{\mathrm{b}} \text {, Alizarin red staining, RUNX2, BMP-2, collagen I, } \\
\text { osteocalcin } \uparrow ; \\
\text { regulate the GR-dependent BMP/Smad pathway }\end{array}$ \\
\hline Yin et al. (2015) & $\begin{array}{l}\text { Human periodontal } \\
\text { ligament }\end{array}$ & $\begin{array}{l}\text { Osteogenic differentiation in dexamethasone } \\
\text { induction } \uparrow\end{array}$ & ALP ${ }^{b}$ activity, RUNX2 ${ }^{c}$, collagen I, osteopontin, osteocalcin $\uparrow$ \\
\hline Wang et al. (2014) & Human dental pulp & Odontogenic/osteogenic differentiation $\uparrow$ & $\begin{array}{l}\text { Dentin sialoprotein, DSPP }{ }^{d}, A^{b} P^{b} \text {, osteocalcin, bone } \\
\text { morphogenetic protein-2, fibroblast growth factor } 2 \uparrow\end{array}$ \\
\hline Huang et al. (2016) & Mouse bone marrow & $\begin{array}{l}\text { Osteogenic differentiation inhibited by } \\
\text { malondialdehyde } \uparrow\end{array}$ & calcium nodule, $A L P^{b}, \operatorname{Run} \times 2^{c} \uparrow$ \\
\hline Xu et al. (2015) & Human adipose tissue & $\begin{array}{l}\text { Cartilage differentiation in osteogenic induction } \\
\text { medium } \uparrow\end{array}$ & $\begin{array}{l}\text { Collagen II, collagen XI, acid phosphatase, cartilage oligomeric } \\
\text { matrix protein, ELASTIN } \uparrow\end{array}$ \\
\hline Wang et al. (2012) & Human dental pulp & Odontoblast-like cells $\uparrow$ & $\mathrm{ALP}^{\mathrm{b}} ; \mathrm{DSPP}{ }^{\mathrm{d}}, \mathrm{DMP} 1^{\mathrm{e}} \uparrow$ \\
\hline $\begin{array}{l}\text { Wang and Yaping } \\
\text { (2012) }\end{array}$ & Human dental pulp & $\begin{array}{l}\text { Rg1 combined with rhBMP-2 promotes } \\
\text { odontogenic differentiation }\end{array}$ & 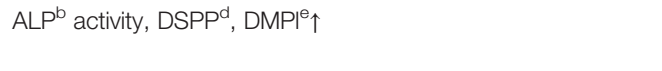 \\
\hline He et al. (2011) & Human bone marrow & $\begin{array}{l}\text { Endothelial differentiation in an indirect coculture } \\
\text { with human umbilical vein endothelial cells } \uparrow\end{array}$ & Von Willebrand factor, VE-cadherin, CD31 \\
\hline Li et al. (2011) & Rat bone marrow & Induced pluripotent stem cell differentiation $\uparrow$ & Nanog, c-Myc, Oct, Klf4, Sox $2 \uparrow$ \\
\hline
\end{tabular}

${ }^{a}$ NSE : Neuron-specific enolase.

${ }^{b}$ ALP : Alkaline phosphatase.

${ }^{c} R U N X 2$ : Runt-related transcription factor 2.

${ }^{d}$ DSPP : Dentin sialophosphoprotein.

${ }^{e} \mathrm{DMP} 1$ : Dentin matrix protein 1.

BMSCs, such as CD31, VWF, and VE-cadherin, in a dosedependent manner. At the same time, electron microscopy showed that the characteristic endothelial Weibel-Palade bodies were observed in BMSCs (He et al., 2011). Animal experiments in vivo have also confirmed that Rg1 can stimulate the myocardial tissue secretion of granulocyte colony-stimulating factor (G-CSF), which promotes the homing of rabbit BMSCs to myocardial tissue and differentiation into vascular endothelial cells. These changes reduced the myocardial infarct size and improved cardiac function (Wang et al., 2005). Notably, restenosis is the most common complication of stent surgery for cardiovascular diseases, and its pathological mechanism involves the delayed formation of vascular endothelial cells and the proliferation of vascular smooth muscle cells (Nobuyoshi et al., 1991; Ferns and Avades, 2000; Tonino et al., 2009). The abovementioned study showed that Rg1 can promote the differentiation of MSCs into vascular endothelial cells. Thus, loading Rg1 or MSCs onto vascular balloons (Schwartz et al., 1990) or stents (Hoffmann et al., 1996; Nakatani et al., 2003) may be an effective method to promote endothelial cell regeneration. Besides, whether Rg1 can combine with MSCs to inhibit the proliferation of vascular smooth muscle cells remains unknown. Therefore, demonstrating that Rg1 combined with MSCs can enhance endothelial cell proliferation while inhibiting smooth muscle cell proliferation will support this hypothesis and provide a strategy for restenosis therapy.
Rg1 can promote the osteogenic differentiation of rat BMSCs and has a protective effect on the malondialdehyde-inhibited osteogenic differentiation of mouse BMSCs. The molecular mechanism involved increased formation of calcium nodules and alkaline phosphatase (ALP) activity and upregulation of the mRNA and protein levels of ALP and Runt-related transcription factor 2 (Runx2) (Gu et al., 2016; Huang et al., 2016). In addition, Rg1 can mobilize glucocorticoid receptors to form homodimers and transfer to the rat BMSC nucleus, promoting the increased transcription of glucocorticoid receptor-sensitive genes, such as mitogen-activated protein kinase phosphatase-1 (MKP-1) and glucocorticoid-regulated kinase (SGK). Then, bone morphogenetic protein-2 (BMP-2) is activated to increase the expression of $\mathrm{p}$-Smad1/5/8 (glucocorticoid receptor-dependent $\mathrm{BMP}-2 / \mathrm{Smad}$ signaling pathway); upregulates the protein expression of osteogenic proteins such as ALP, CON, COL1, BMP-2, and Runx2 in BMSCs; enhances bone calcification; and finally, promotes bone healing in rats (Gu et al., 2016). The positive effect of $\operatorname{Rg} 1$ on the osteogenic differentiation of BMSCs has been established. However, periosteal tissues and periosteal stem cells are the main mobilization components involved in bone repair after a fracture (Tonna, 1960; Debnath et al., 2018). How Rg1 promotes the differentiation of BMSCs into bone cells in the bone "stem cell niche" to promote fracture healing still needs to be elucidated. Furthermore, whether the intraperitoneally injected Rg1 described in the above study mainly exerts 


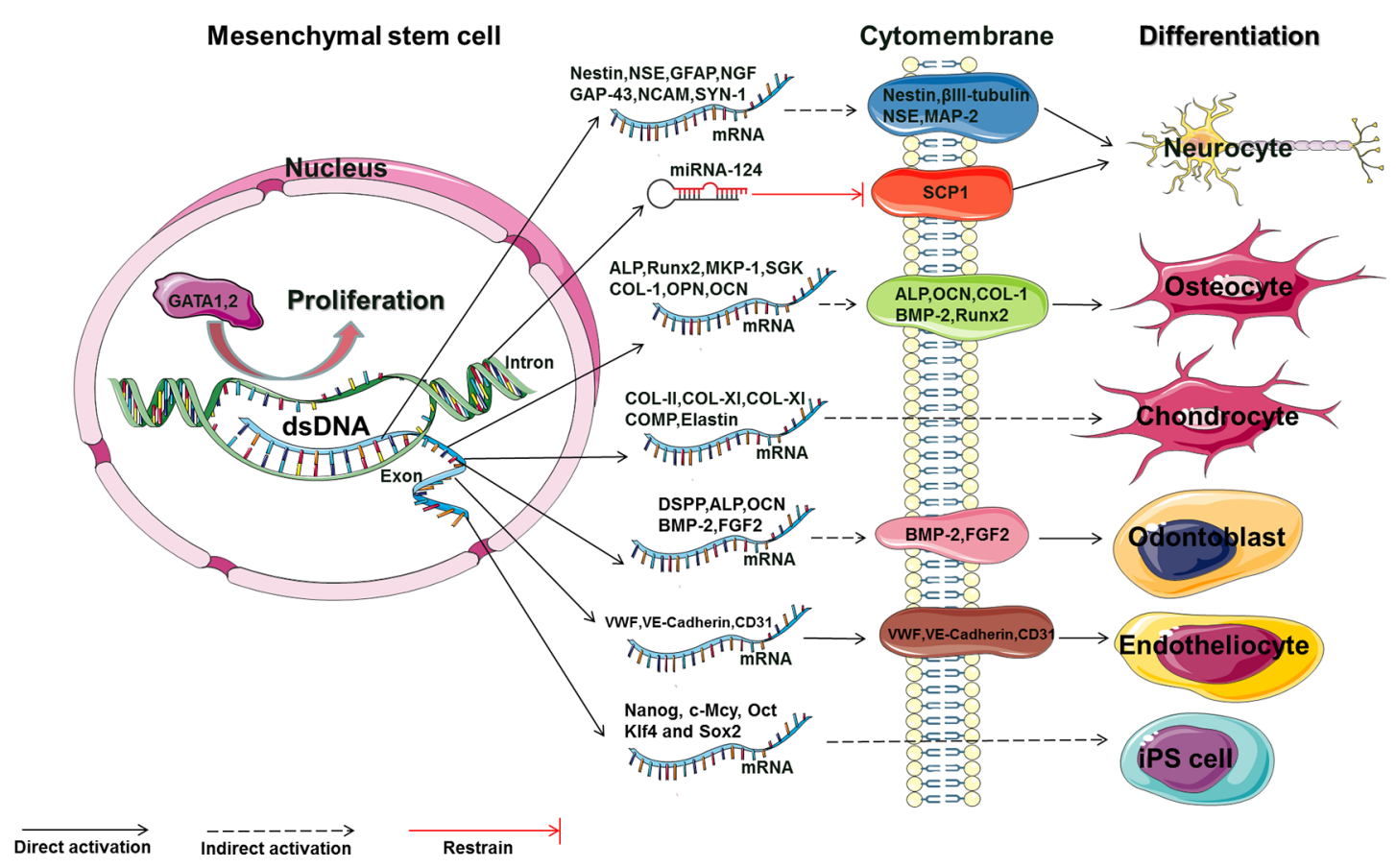

FIGURE 2 | The main molecular mechanism by which Rg1 affects the proliferation and differentiation of MSCs (GATA, GATA-binding factor; NSE, neuron-specific enolase; GFAP, glial fibrillary acidic protein; NGF, nerve growth factor; GAP-43, growth-associated protein 43; NCAM, neural cell adhesion molecule; SYN, synaptophysin; MAP-2, microtubule-associated protein 2; SCP-1, small C-terminal domain phosphatase 1; ALP, alkaline phosphatase; OCN, osteocalcin; COL, collagen; BMP-2, bone morphogenetic protein 2; RUNX2, runt-related transcription factor 2; COMP, cartilage oligomeric matrix protein; DSPP, dentin sialophosphoprotein; BMP-2, bone morphogenetic protein 2; FGF2, fibroblast growth factor 2; vWF, von Willebrand factor; VE-cadherin, vascular endothelial cadherin; Nanog, c-Mcy, Oct, Klf4 and Sox2: embryonic stem cell-related transcription factors).

osteogenic and bone-healing effects by directly acting on periosteal stem cells in rats requires further confirmation.

In $\alpha$-MEM culture, addition of $\operatorname{Rg} 1(6.25 \mu \mathrm{mol} / \mathrm{L})$ to cultured rat BMSCs for 30 days increased the mRNA levels of Nanog, cMcy, Oct, Klf4, and Sox2. Some scholars believe that Nanogpositive cells and embryonic stem cells are difficult to distinguish via their gene expression profiles. Therefore, based on gene expression analyses, they concluded that Rg1 may promote the conversion of BMSCs to induced pluripotent stem cells (iPSs) (Takahashi et al., 2007; Li et al., 2011). However, it is difficult to explain the iPS-promoting effect of Rg1 based only on gene expression. At the same time, one study also showed that $1 \mu \mathrm{g} / \mathrm{ml}$ Rg1 can effectively increase the efficiency of mouse embryonic fibroblast conversion to iPSs (Hu et al., 2014). The success rate of Rg1-induced iPSs and the tumorigenicity and safety of the induced iPSs in the above studies require further analyses.

Compared with BMSCs, adipose-derived MSCs (ADSCs) are easy to obtain and result in less trauma during tissue extraction, indicating that they are ideal seed cells for tissue engineering (Puissant et al., 2005; Kern et al., 2006; Bourin et al., 2013). Rg1 and platelet fibrin (PRF) can enhance the proliferation, differentiation, and soft tissue regeneration of human breast adipose ADSCs in collagen type I sponge scaffolds in vitro and in vivo. Three weeks after the subcutaneous transplantation of Rg1 in combination with PRF-treated human breast ADSC- loaded type I sponge scaffolds, the "adipose tissue block" wet weight, number of adipocytes, intracellular lipid levels, microvascular density, and gene and protein levels of VEGF, HIF- $1 \alpha$, and PPAR $\gamma$ were significantly improved, and a broad new organizational network was also formed. These results suggested that Rg1 and PRF combined with 3D culture can enhance the effects of MSCs in soft tissue regeneration in tissue engineering studies (Xu et al., 2016). However, the occurrence of related risk factors, such as tumors and cancer, must be considered in the formation of various new tissues. For instance, RUNX2 is a transcription factor belonging to the RUNX family and plays a key role in osteoblast differentiation (Komori, 2018). This molecule is also considered a marker of MSCs found in tumors and is involved in various signaling pathways of cancer growth processes (Ozaki et al., 2018). New research has found that lyophilized PRF can mediate Runx2enhanced craniofacial bone regeneration ( $\mathrm{Li}$ et al., 2014). Furthermore, $\operatorname{Rg} 1$ can stimulate human umbilical vein endothelial cells to undergo angiogenesis via the miR-23a/ RUNX2/VEGF-A pathway (Wu et al., 2017). Therefore, key factors, such as the presence of bone tissue components in the "adipose tissue block" induced by PRF and Rg1 and the correlation between Runx2 expression in transplanted adipose stem cells and tumor formation, must be clarified before clinical trials. 
Rg1 can increase the proliferation and neurodifferentiation of human ADSCs. In human ADSCs grown in nerve-inducing medium, Rg1 at concentrations of 10,50 , and $100 \mu \mathrm{g} / \mathrm{ml}$ can gradually increase proliferation; enhance the gene transcription levels of growth-associated protein 43 (GAP-43), neural cell adhesion molecule (NCAM), and synapse protein 1 (SYN-1); and increase the protein expression levels of NSE and microtubule-associated protein-2 (MAP-2) (Xu et al., 2014). In addition, Rg1 can increase the expression of miRNA-124, degrade the protein expression of the neuronal differentiation inhibitor small C-terminal domain phosphatase 1, and increase the protein levels of nestin and $\beta I I I-$ tubulin, thereby promoting the differentiation of ADSCs into nerve-like cells after induction by isobutylmethylxanthine (IBMX) (Dong et al., 2017). In cartilage-inducing medium, $\operatorname{Rg} 1$ can enhance the proliferative capacity of third-generation human breast ADSCs in the early stage (6 days after seeding) and promote the phenotypic differentiation of chondrocytes in the late phase ( 2 weeks after seeding) by, for example, enhancing the mRNA levels of collagen type II (CO-II), collagen type XI (CO-XI), acid phosphatase (CO-XI), cartilage oligomeric matrix protein (COMP), and ELASTIN (elastin). Researchers have suggested that thirdgeneration human ADSCs can be used for in vitro cartilage regeneration and that the addition of $\operatorname{Rg} 1$ at different time points can effectively regulate the proliferation and cartilage differentiation of human breast ADSCs (Xu et al., 2015).

Rg1 can promote the proliferation of dental pulp and PDLSCs, the differentiation of human dental pulp stem cells (DPSCs) into odontoblasts, and the differentiation of human PDLSCs into osteoblasts, indicating its promising application prospects in the field of dental and oral and maxillofacial regenerative medicine. Rg1 can promote the proliferation and differentiation of human DPSCs via 2059 differentially expressed genes; for example, Rg1 increases the gene expression of DSPP, DMP1, ALP, OCN, BMP-2, and FGF2 and the protein expression of BMP-2 and FGF2 in DPSCs (Wang et al., 2012, 2014). At the same time, the combination of Rg1 and rhBMP-2 can enhance the odontogenetic differentiation of human DPSCs (Wang and Yaping, 2012). Therefore, the application of Rg1 as a pulp capping agent in clinical pulp capping surgery may be a new breakthrough for the promotion of DPSC proliferation and differentiation, which will be beneficial for regenerating dental pulp and promoting the subsequent formation of reparative dentin. A $10 \mu \mathrm{mol} / \mathrm{L} \mathrm{Rg} 1$ solution can increase the proliferation of PDLSCs and enhance the ALP, RUNX2, collagen I, osteopontin (OPN), and osteocalcin (OCN) expression in hPDLSCs, ultimately promoting the osteogenic differentiation of human PDLSCs. However, concentrations of Rg1 exceeding $100 \mu \mathrm{mol} / \mathrm{L}$ inhibited cell proliferation (Yin et al., 2015). Interestingly, dental pulp, periodontal ligaments, dentin, cementum, and intrinsic alveolar bone all originate from ectodermal mesenchymal tissue (exo-mesenchymal), which is developed from ectodermal neural crest cells. Nerve-supporting cells or neurogliocytes (Schwann cells and Schwann cell precursors, etc.) transfer to the dental pulp tissues during early development to form dental pulp MSCs (Kaukua et al., 2014).
This phenomenon indicates that the MSCs stored in the connective tissue of the oral cavity, especially in dents, may be different from traditional mesenchymal-derived MSCs and may show enhanced neurological differentiation.

\section{RG1 RELIEVES THE AGING OF MSCS}

With the increase in MSC passage number in vitro and the aging of human organs, telomere length shortens after each division cycle, which leads to gradual senescence (Fehrer and Lepperdinger, 2005; Alt et al., 2012). The mean telomere length of BMSCs decreased from $9.19 \mathrm{kbp}$ to $8.7 \mathrm{kbp}$ from passages 1 to 9 (Bonab et al., 2006). Mesenchymal and hematopoietic stem cells can form a unique bone marrow niche, the members of which are closely related and influence each other (Wilson and Trumpp, 2006; Méndez-Ferrer et al., 2010). Rg1 can enhance the antiaging effects of hematopoietic stem cells and the hematopoietic microenvironment (partly by regulating the secretion of MSCs), prevent cognitive impairment and hippocampus senescence, antagonize spleen and thymus damage induced by D-galactose (D-gal), and ameliorate induced aging animal models by alleviating oxidative stress injury and downregulating the expression of senescence-associated proteins (Zhu et al., 2014; Tang et al., 2015; Sun et al., 2018). Similarly, Rg1 has antiaging effects on MSCs and cooperates with other supporting cells to protect tissues and organs. After rats were treated with D-gal and Rg1, BMSCs were extracted from the bone marrow for culture. In three-passage cultures, the MSCs isolated from $\mathrm{Rg} 1$-treated rats showed enhanced antioxidant and anti-inflammatory properties and a strong ability to resist hematopoietic microenvironment senescence, exhibiting features such as a reduced percentage of SA- $\beta$-gal+ cells, reduced reactive oxygen species (ROS) levels, reduced malondialdehyde (MDA) activity, and reduced expression of inflammatory markers (IL-6, IL-2, TNF- $\alpha$ ) and senescenceassociated proteins (p16, p21, p53) as well as an increased S phase cell percentage, increased superoxide dismutase (SOD) activity, and increased stem cell factor (SCF) expression. At the same time, $\operatorname{Rg} 1$ also showed increased antioxidant and partial anti-inflammatory properties in normal rats (Hu et al., 2015). These results indicate that $\mathrm{Rg} 1$ can regulate MSCs to affect the microenvironment and thus enhance hematopoiesis. This finding suggests a new strategy for addressing the insufficient hematopoietic stem cell quantity, the low homing rate of transplanted hematopoietic stem cells, and the delayed implantation of hematopoietic stem cells in the bone marrow during hematopoietic stem cell transplantation.

Furthermore, the fact that different culture environmental conditions can also affect telomeres and significantly increase or decrease the culture life span in vitro (von Zglinicki et al., 1995) still needs to be addressed. Thus, the culture and treatment of MSCs with Rg1 may minimize the effect of serum-free medium, the culture temperature, and the oxygen content on aging in vitro, which need to be investigated before MSCs can be used therapeutically. 
TABLE 3 | Ginsenoside Rg1 inhibits MSC apoptosis in vitro.

\begin{tabular}{|c|c|c|c|c|}
\hline Study & MSC source & $\begin{array}{l}\text { Reagent for cell } \\
\text { apoptosis }\end{array}$ & Effects & Related mechanism \\
\hline Gu et al. (2016) & Rat bone marrow & Dexamethasone? & $\begin{array}{l}\text { Inhibit apoptosis; } \\
\text { Annexin V/propidium iodide } \downarrow\end{array}$ & \\
\hline Hu et al. (2016) & Rat bone marrow & $\mathrm{H}_{2} \mathrm{O}_{2}$ & $\begin{array}{l}\text { inhibit apoptosis; } \\
\text { TUNEL staining, Annexin V/propidium iodide } \downarrow\end{array}$ & 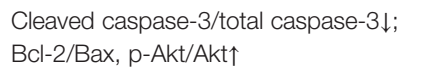 \\
\hline Liu et al. (2016) & $\begin{array}{l}\text { Human umbilical } \\
\text { cord blood }\end{array}$ & $\begin{array}{l}\text { Tert-Butyl } \\
\text { hydroperoxide }\end{array}$ & $\begin{array}{l}\text { Inhibit apoptosis; } \\
\text { Annexin V-FITC/7-AAD, TUNEL-positive cells, condensation } \\
\text { and fragmentation of nuclei } \downarrow\end{array}$ & $\begin{array}{l}\text { Activate the Akt-FoxO3a-Bim pathway; } \\
\text { LDH, MDA, cleaved caspase-3, Bim, } \\
\text { FoxO3a (nucleus) } \downarrow ; \\
\text { Bcl-2/Bax, SOD, pAKT/AKT, pFoxO3a/ } \\
\text { FoxO3a, FoxO3a (cytoplasm) } \uparrow\end{array}$ \\
\hline Guo et al. (2017) & $\begin{array}{l}\text { Human bone } \\
\text { marrow }\end{array}$ & $\begin{array}{l}\text { Hypoxia- } \\
\text { reoxygenation }\end{array}$ & Inhibit apoptosis & $\begin{array}{l}\mathrm{Bcl}-2 \downarrow \\
\mathrm{Bax} \uparrow\end{array}$ \\
\hline Li et al. (2013) & $\begin{array}{l}\text { Mouse bone } \\
\text { marrow }\end{array}$ & Malondialdehyde & $\begin{array}{l}\text { Rg1-loaded alginate-chitosan microspheres inhibit } \\
\text { apoptosis; } \\
\text { TUNEL-positive cells } \downarrow\end{array}$ & $\begin{array}{l}\text { Bax, caspase- } 3 \downarrow \\
\text { Bcl- } 2 \uparrow\end{array}$ \\
\hline Fu and Zheng (2013) & Rat bone marrow & $\begin{array}{l}\text { Hypoxia/serum } \\
\text { deprivation }\end{array}$ & $\begin{array}{l}\text { Inhibit apoptosis; } \\
\text { Annexin V-FITC/propidium iodide } \downarrow\end{array}$ & $\begin{array}{l}\text { Stable mitochondrial membrane } \\
\text { structure and function; } \\
\text { caspase-3 activity, Bad, Bax } \downarrow ; B c l-2 \uparrow\end{array}$ \\
\hline
\end{tabular}

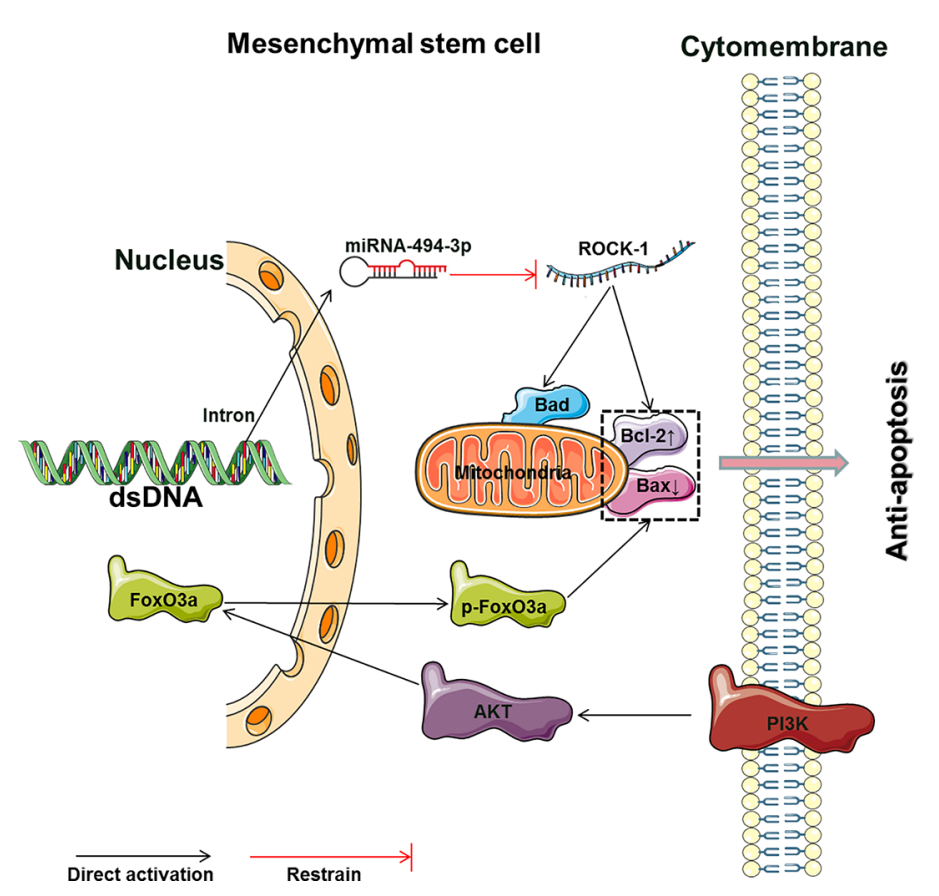

FIGURE 3 | The main molecular mechanism by which Rg1 affects the apoptosis of MSCs (Bad, Bcl2-associated agonist of cell death; Bcl-2, B cell lymphoma 2; Bax, B cell lymphoma/leukemia-2-associated X protein; ROCK-1, Rho-associated coiled-coil containing protein kinase 1; PI3K, phosphoinositide 3-kinases; AKT, protein kinase B; FoxO3, forkhead box O3; p-FoxO3, phosphorylated forkhead box O3).

\section{RG1 INHIBITS MSC APOPTOSIS}

To maintain a stable environment in the body, genes control the autonomous and orderly death of cells (Wyllie et al., 1980; Schwartz and Osborne, 1993). A study showed that more than 99\% of MSCs injected into the left ventricle of CB17 SCID/beige adult mice died within 4 days of injection, which reflects the harsh, proapoptotic microenvironment of the infarcted heart; this environment may not be conducive to MSC survival (Geng, 2003). Hence, protection of MSCs from apoptosis may improve their success rate in treating tissue ischemia and hypoxia-related diseases (Zhu et al., 2006).

$\mathrm{Rg} 1$ has extensive antiapoptotic effects in different apoptotic models (Table 3, Figure 3). Rg1 can reduce apoptosis and increase the water content in the brain tissues of ischemiareperfusion rats. Transplanted human BMSCs in rats can 
TABLE 4 | Animal experimental studies of ginsenoside Rg1 regulating MSCs in vivo.

\begin{tabular}{|c|c|c|c|c|c|c|}
\hline Study & Animal model & $\begin{array}{c}\text { Rg1 } \\
\text { dosage }\end{array}$ & Administration methods & Study object & Therapeutic effect & Related mechanism \\
\hline Xu et al. (2016) & Untreated nude mice & $10 \mu \mathrm{g} / \mathrm{ml}$ & $\begin{array}{l}\text { Collagen scaffold-loaded } \\
\text { adipose MSCs plus Rg1 or/ } \\
\text { and PRF mouse } \\
\text { subcutaneous transplantation }\end{array}$ & $\begin{array}{l}\text { Scaffold } \\
\text { transplant }\end{array}$ & $\begin{array}{l}\text { Wet weight of the transplant, } \\
\text { adipogenesis, microvessel } \\
\text { density } \uparrow\end{array}$ & PPAR $\gamma, \mathrm{HIF}-1 \alpha, \mathrm{VEGF} \uparrow$ \\
\hline Gu et al. (2016) & Rat tibial fracture model & $\begin{array}{l}20 \mathrm{mg} / \mathrm{kg} \\
\text { per day }\end{array}$ & Rg1 intraperitoneal injection & Fractured tibia & $\begin{array}{l}\text { Improved H\&E staining, } \\
\text { Safranin-O/Light Green Red } \\
\text { staining, bone mineral } \\
\text { density, bone volume, } \\
\text { trabecular number, trabecular } \\
\text { separation }\end{array}$ & \\
\hline Hu et al. (2015) & $\begin{array}{l}\text { D-Galactose-induced } \\
\text { aged rat model }\end{array}$ & $\begin{array}{l}20 \mathrm{mg} / \mathrm{kg} \\
\text { per day }\end{array}$ & $\begin{array}{l}\text { Rg1 intraperitoneal injection } \\
\text { of rats and extracted BMSCs } \\
\text { for analysis }\end{array}$ & $\begin{array}{l}\text { BMSCs from } \\
\text { aged rats }\end{array}$ & & 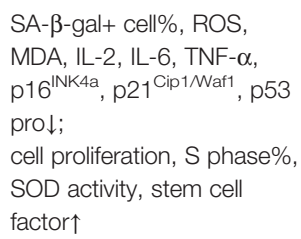 \\
\hline Hu et al. (2015) & Normal rats & $\begin{array}{l}20 \mathrm{mg} / \mathrm{kg} \\
\text { per day }\end{array}$ & $\begin{array}{l}\text { Rg1 intraperitoneal injection } \\
\text { of rats and extracted BMSCs } \\
\text { for analysis }\end{array}$ & $\begin{array}{l}\text { BMSCs from } \\
\text { aged rats }\end{array}$ & & $\begin{array}{l}\text { SA- } \beta \text {-gal+ cell\%, G1 phase } \\
\%, \text { ROS, MDA, IL-6,p16 } \downarrow \text {; } \\
\text { cell proliferation, TNF- } \alpha, \text { S } \\
\text { phase } \%, \text { SOD activity } \uparrow\end{array}$ \\
\hline Bao et al. (2015) & $\begin{array}{l}\text { MCAO and reperfusion } \\
\text { models (intraluminal } \\
\text { vascular occlusion } \\
\text { method) }\end{array}$ & $\begin{array}{l}20 \mathrm{mg} / \mathrm{kg} \\
\text { per day }\end{array}$ & $\begin{array}{l}\text { Rat BMSC venous } \\
\text { transplantation followed by } \\
\text { Rg1 intraperitoneal injection }\end{array}$ & $\begin{array}{l}\text { Rat ipsilateral } \\
\text { and } \\
\text { contralateral } \\
\text { hemispheres }\end{array}$ & $\begin{array}{l}\text { Brain edema, infarct volume } \downarrow \text {; } \\
\text { neurological outcome } \uparrow\end{array}$ & $\begin{array}{l}\text { TUNEL staining, Bax pro } \downarrow \text {; } \\
\text { neuron-specific enolase, } \\
\text { glial fibrillary acidic pro, Bcl- } \\
2 \text { pro, Bcl-2/Bax } \uparrow\end{array}$ \\
\hline $\begin{array}{l}\text { Zheng et al. } \\
\text { (2018) }\end{array}$ & $\begin{array}{l}\text { Hind limb ischemia } \\
\text { model }\end{array}$ & $\begin{array}{l}100 \mu \mathrm{g} / \mathrm{ml} \\
\text { (cultured } \\
\text { with } \\
\text { BMSCs) }\end{array}$ & $\begin{array}{l}\text { BMSCs treated with Rg1 } \\
\text { orthotopic transplantation }\end{array}$ & $\begin{array}{l}\text { Gastrocnemius } \\
\text { and tibialis } \\
\text { anterior muscle }\end{array}$ & $\begin{array}{l}\text { Improved the survival of } \\
\text { transplanted BMSCs and } \\
\text { enhanced the therapeutic } \\
\text { effects }\end{array}$ & 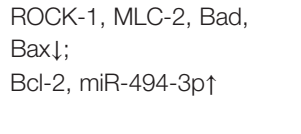 \\
\hline $\begin{array}{l}\text { Wang et al. } \\
\text { (2005) }\end{array}$ & $\begin{array}{l}\text { Rabbit myocardial } \\
\text { infarction model }\end{array}$ & $\begin{array}{l}10 \mathrm{mg} / \\
(\mathrm{kg} \cdot \mathrm{d})\end{array}$ & $\begin{array}{l}\text { Rabbit BMSC iliac } \\
\text { transplantation followed by } \\
\text { Rg1 treatment }\end{array}$ & Rabbit heart & $\begin{array}{l}\text { Area of myocardial } \\
\text { infarction } \downarrow \text {; } \\
\text { cardiac function; regeneration } \\
\text { of myocardial endothelial } \\
\text { cells } \uparrow\end{array}$ & $\begin{array}{l}\text { Granulocyte colony- } \\
\text { stimulating factor in cardiac } \\
\text { muscle } \uparrow\end{array}$ \\
\hline
\end{tabular}

differentiate into neurons and neurogliocytes to improve cerebral ischemia. More importantly, Rg1 combined with human BMSCs showed better antiapoptotic effects and resulted in better brain recovery than single Rg1 or BMSC treatments (Bao et al., 2015). $\mathrm{Rg} 1$ can counteract the apoptosis of BMSCs induced by various stimuli, and the expression levels and ratio of Bcl-2/Bax are key factors in the Rg1-induced resistance of BMSCs to apoptosis. Rg1 can reduce Bax expression and enhance Bcl-2 expression to protect against hypoxia-reoxygenation-induced apoptosis of human BMSCs (Guo et al., 2017), MDA-induced apoptosis of mouse BMSCs (Li et al., 2013), and hypoxia and serum deprivation-induced apoptosis of rat BMSCs (Fu and Zheng, 2013). Rg1 can also activate the phosphoinositide 3-kinase/ protein kinase B (PI3K/Akt) signaling pathway to protect against the hydrogen peroxide $\left(\mathrm{H}_{2} \mathrm{O}_{2}\right)$-induced apoptosis of rat BMSCs. The mechanism involves downregulating Bax, cleaving caspase-3, and upregulating Bcl-2 and phosphorylated Akt at the protein level ( $\mathrm{Hu}$ et al., 2016). Furthermore, in an in vivo experiment involving the in situ injection of Rg1-treated rat BMSCs to treat hindlimb arterial embolization in rats, Rg1 improved the survival of transplanted BMSCs and protected BMSCs from apoptosis induced by ischemia. The Rg1 mechanisms in the above study involve the activation and upregulation of miR-494-3p to inhibit ROCK-1 gene expression, upregulation of the antiapoptotic gene $\mathrm{Bcl}-2$, downregulation of the proapoptotic genes Bax and Bad, inhibition of the Bax and Bcl-2 protein interaction to prohibit heterodimer formation, and inhibition of the release of cytochrome $\mathrm{C}$ from mitochondria and caspase-3 activation (Zheng et al., 2018).

Tert-butyl hydroperoxide (t-BHP) was shown to reduce the $\mathrm{Bcl}-2 / \mathrm{Bax}$ ratio and stimulate ROS formation to enhance apoptosis (Kowaltowski and Fiskum, 2005; Lee et al., 2012). Rg1 can enhance the survival rate and antiapoptotic effects of human umbilical cord blood-derived stromal cells (hUCBDSCs) induced by t-BHP. The mechanism involves activation of the PI3K-Akt pathway and induction of FoxO3a phosphorylation, resulting in the translocation of FoxO3a from the nucleus to the cytoplasm; these changes reduce Bim expression and increase the $\mathrm{Bcl}-2 / \mathrm{Bax}$ ratio to inhibit apoptosis (Liu et al., 2016). Interestingly, MSCs can reside in a state of reversible growth arrest, or quiescence, for prolonged periods of time, and cells in this state are called "idle" stem cells (van Velthoven and Rando, 2019). Do nonapoptotic MSCs protected by $\operatorname{Rg} 1$ remain in an "idle" state? Clarifying this question may explain the mechanism underlying the functional maintenance of quiescent "idle" MSCs 
and activation of MSCs to modify tissue homeostasis in a specific environment, such as hypoxia and ischemia.

\section{CONCLUSIONS AND REMARKS}

We comprehensively visualized the main molecular mechanism by which Rg1 affects the proliferation, differentiation, and apoptosis of MSCs described in the above papers (Figures 2 and 3). This result may provide a useful reference and ideas for further experimental research on Rg1. In summary, Rg1 shows promising application prospects with regard to MSCs and its microenvironmental regulatory effects in vitro and in several animal disease models in vivo (Table 4). During the expansion of pretreatment MSCs in vitro, various uncontrollable factors, such as differences in culture systems, culture environment, and reagents, may be encountered, which may affect the MSC quality before clinical infusion or use in tissue engineering. The application of Rg1 may provide an effective solution for these issues. Furthermore, although current studies have shown that $\mathrm{Rg} 1$ can effectively regulate the proliferation and differentiation of MSCs while controlling senescence and apoptosis in vivo, how to minimize the toxicity of $\mathrm{Rg} 1$, how Rg1 functions in a specific "stem cell niche," how to utilize Rg1 to precisely regulate $\mathrm{MSC}$-directed differentiation in the microenvironment, and how Rg1 affects the balance between "idle" and activated MSC populations to maintain homeostasis or repair the human body still require additional, indepth studies.

\section{REFERENCES}

Alison, M. R., Poulsom, R., Jeffery, R., Dhillon, A. P., Quaglia, A., Jacob, J., et al. (2000). Hepatocytes from non-hepatic adult stem cells. Nature 406, 257. doi: $10.1038 / 35018642$

Alt, E. U., Senst, C., Murthy, S. N., Slakey, D. P., Dupin, C. L., Chaffin, A. E., et al. (2012). Aging alters tissue resident mesenchymal stem cell properties. Stem Cell Res. 8, 215-225. doi: 10.1016/j.scr.2011.11.002

Bao, C., Wang, Y., Min, H., Zhang, M., Du, X., Han, R., et al. (2015). Combination of ginsenoside Rg1 and bone marrow mesenchymal stem cell transplantation in the treatment of cerebral ischemia reperfusion injury in rats. Cell. Physiol. Biochem. 37, 901-910. doi: 10.1159/000430217

Bonab, M. M., Alimoghaddam, K., Talebian, F., Ghaffari, S. H., Ghavamzadeh, A., and Nikbin, B. (2006). Aging of mesenchymal stem cell in vitro. BMC Cell Biol. 7, 14. doi: 10.1186/1471-2121-7-14

Bourin, P., Bunnell, B. A., Casteilla, L., Dominici, M., Katz, A. J., March, K. L., et al. (2013). Stromal cells from the adipose tissue-derived stromal vascular fraction and culture expanded adipose tissue-derived stromal/stem cells: a joint statement of the International federation for adipose therapeutics and science (IFATS) and the international society for cellular therapy (ISCT). Cytotherapy 15, 641-648. doi: 10.1016/j.jcyt.2013.02.006

Bruder, S. P., Jaiswal, N., and Haynesworth, S. E. (1997). Growth kinetics, selfrenewal, and the osteogenic potential of purified human mesenchymal stem cells during extensive subcultivation and following cryopreservation. J. Cell. Biochem. 64, 278-294. doi: 10.1002/(SICI)1097-4644(199702)64:2<278::AIDJCB11>3.0.CO;2-F

Bruder, S. P., Kurth, A. A., Shea, M., Hayes, W. C., Jaiswal, N., and Kadiyala, S. (1998). Bone regeneration by implantation of purified, culture-expanded human mesenchymal stem cells. J. Orthop. Res. 16, 155-162. doi: 10.1002/ jor. 1100160202

\section{AUTHOR CONTRIBUTIONS}

Conceptualization: FH. Methodology: FH and TL. Software: FH. Validation: FH. Formal analysis: FH and CY. Investigation: FH and HJ. Resources: FH. Data curation: FH. Writing-original draft preparation: FH. Writing-review and editing: FH and CY. Visualization: FH. Supervision: FH. Project administration: FH and TL. Funding acquisition: FH.

\section{FUNDING}

This work was supported by the Master's Startup Fund of Zunyi Medical College (Yuan Zi [2017] No. 29) and the Traditional Chinese Medicine and Ethnic Medicine Science and Technology Research Project of Guizhou Province (QZYY-2018-113).

\section{ACKNOWLEDGMENTS}

We thank Professor Limei Yu and Dr. Yuxiang Li for their support.

\section{SUPPLEMENTARY MATERIAL}

The Supplementary Material for this article can be found online at: https://www.frontiersin.org/articles/10.3389/fphar.2019. 01565/full\#supplementary-material

Chamberlain, G., Fox, J., Ashton, B., and Middleton, J. (2007). Concise review: mesenchymal stem cells: their phenotype, differentiation capacity, immunological features, and potential for homing. Stem Cells 25, 2739-2749. doi: 10.1634/stemcells.2007-0197

Chan, R. Y., Chen, W. F., Dong, A., Guo, D., and Wong, M. S. (2002). Estrogenlike activity of ginsenoside $\mathrm{Rg} 1$ derived from Panax notoginseng. J. Clin. Endocrinol. Metab. 87, 3691-3695. doi: 10.1210/jcem.87.88717

Crigler, L., Robey, R. C., Asawachaicharn, A., Gaupp, D., and Phinney, D. G. (2006). Human mesenchymal stem cell subpopulations express a variety of neuro-regulatory molecules and promote neuronal cell survival and neuritogenesis. Exp. Neurol. 198, 54-64. doi: 10.1016/j.expneurol.2005.10.029

Deans, R. J., and Moseley, A. B. (2000). Mesenchymal stem cells: biology and potential clinical uses. Exp. Hematol. 28, 875-884. doi: 10.1016/S0301-472X (00)00482-3

Debnath, S., Yallowitz, A. R., McCormick, J., Lalani, S., Zhang, T., Xu, R., et al. (2018). Discovery of a periosteal stem cell mediating intramembranous bone formation. Nature 562, 133-139. doi: 10.1038/s41586-018-0554-8

Dong, J., Zhu, G., Wang, T. C., and Shi, F. S. (2017). Ginsenoside Rg1 promotes neural differentiation of mouse adipose-derived stem cells via the miRNA-124 signaling pathway. J. Zhejiang Univ. Sci. B 18, 445-448. doi: 10.1631/jzus.B1600355

Ellis, J. M., and Reddy, P. (2002). Effects of Panax ginseng on quality of life. Ann. Pharmacother. 36, 375-379. doi: 10.1345/aph.1A245

Fang, H., and Limei, Y. (2016). Effects of ginsenoside Rg1 on characteristics and functions of adult stem cells. Chin. Pharmacol. Bull. 32, 319-322. doi: 10.3969/ j.issn.1001-1978.2016.03.005

Fehrer, C., and Lepperdinger, G. (2005). Mesenchymal stem cell aging. Exp. Gerontol. 40, 926-930. doi: 10.1016/j.exger.2005.07.006

Ferns, G. A., and Avades, T. Y. (2000). The mechanisms of coronary restenosis: insights from experimental models. Int. J. Exp. Pathol. 81, 63-88. doi: 10.1046/ j.1365-2613.2000.00143.x 
Fu, X.-K., and Zheng, H.-Z. (2013). The protective effect of ginsenoside Rg1 on rat bone marrow mesenchymal stem cell apoptosis. Chin. J. Clin. 7, 3454-3459. doi: 10.3877/cma.j.issn.1674-0785.2013.08.105

Geng, Y. J. (2003). Molecular mechanisms for cardiovascular stem cell apoptosis and growth in the hearts with atherosclerotic coronary disease and ischemic heart failure. Ann. N.Y. Acad. Sci. 1010, 687-697. doi: 10.1196/annals.1299.126

Gu, Y., Zhou, J., Wang, Q., Fan, W., and Yin, G. (2016). Ginsenoside Rg1 promotes osteogenic differentiation of rBMSCs and healing of rat tibial fractures through regulation of GR-dependent BMP-2/SMAD signaling. Sci. Rep. 6, 25282. doi: $10.1038 /$ srep25282

Guo, Y. H., Zhao, S., Du, Y. X., Xing, Q. J., Chen, B. L., and Yu, C. Q. (2017). Effects of ginsenoside Rg1-loaded alginate-chitosan microspheres on human bone marrow stromal cells. Biosci. Rep. 37 (3), BSR20160566. doi: 10.1042/bsr20160566

He, W., Wu, W. K., Wu, Y. L., Yang, X. H., Lin, Q. X., and Yu, W. H. (2011). Ginsenoside-Rg1 mediates microenvironment-dependent endothelial differentiation of human mesenchymal stem cells in vitro. J. Asian Nat. Prod. Res. 13, 1-11. doi: 10.1080/10286020.2010.535519

He, F., Zhou, A., and Feng, S. (2018a). Use of human amniotic epithelial cells in mouse models of bleomycin-induced lung fibrosis: a systematic review and meta-analysis. PloS One 13, e0197658. doi: 10.1371/journal.pone.0197658

He, F., Zhou, A., Feng, S., Li, Y., and Liu, T. (2018b). Mesenchymal stem cell therapy for paraquat poisoning: a systematic review and meta-analysis of preclinical studies. PloS One 13, e0194748. doi: 10.1371/journal.pone.0194748

Hoffmann, R., Mintz, G. S., Dussaillant, G. R., Popma, J. J., Pichard, A. D., Satler, L. F., et al. (1996). Patterns and mechanisms of in-stent restenosis. A serial intravascular ultrasound study. Circulation 94, 1247-1254. doi: 10.1161/01.cir.94.61247

Hu, W., Zuo, Q., Fang, Z., Qiu, Z., and Zhang, S. (2014). Roles of ginsenoside Rg1 in the induction of mouse induced pluripotent stem cells. Neural Inj. Funct. Reconstr. 9, 184-186. doi: 10.3870/sjsscj.2014.03.004

Hu, W., Jing, P., Wang, L., Zhang, Y., Yong, J., and Wang, Y. (2015). The positive effects of ginsenoside Rg1 upon the hematopoietic microenvironment in a Dgalactose-induced aged rat model. BMC Complement. Altern. Med. 15, 119. doi: 10.1186/s12906-015-0642-3

Hu, J., Gu, Y., and Fan, W. (2016). Rg1 protects rat bone marrow stem cells against hydrogen peroxide-induced cell apoptosis through the PI3K/Akt pathway. Mol. Med. Rep. 14, 406-412. doi: 10.3892/mmr.20165238

Huang, S.-Y., Chen, J.-Y., Wang, Y.-A., Zhang, J., and Li, Y. (2016). Protective effect of ginsenoside Rg1 against MDA-suppressed osteogenic differentiation of mesenchymal stem cells. Life Sci. Res. 20, 140-144. doi: 10.16605/j.cnki.10077847.2016.02.009

Ikada, Y. (2006). Challenges in tissue engineering. J. R. Soc Interface 3, 589-601. doi: $10.1098 /$ rsif.20060124

Ikebe, C., and Suzuki, K. (2014). Mesenchymal stem cells for regenerative therapy: optimization of cell preparation protocols. BioMed. Res. Int. 2014, 11. doi: $10.1155 / 2014 / 951512$

Jiang, Y., Jahagirdar, B. N., Reinhardt, R. L., Schwartz, R. E., Keene, C. D., OrtizGonzalez, X. R., et al. (2002). Pluripotency of mesenchymal stem cells derived from adult marrow. Nature 418, 41-49. doi: 10.1038/nature00870

Jin, S., Jeon, J. H., Lee, S., Kang, W. Y., Seong, S. J., Yoon, Y. R., et al. (2019). Detection of 13 ginsenosides (Rb1, Rb2, Rc, Rd, Re, Rf, Rg1, Rg3, Rh2, F1, compound K, 20(S)-protopanaxadiol, and 20(S)-protopanaxatriol) in human plasma and application of the analytical method to human pharmacokinetic studies following two week-repeated administration of red ginseng extract. Molecules 24, 2618. doi: 10.3390/molecules 24142618

Kaukua, N., Shahidi, M. K., Konstantinidou, C., Dyachuk, V., Kaucka, M., Furlan, A., et al. (2014). Glial origin of mesenchymal stem cells in a tooth model system. Nature 513, 551-554. doi: 10.1038/nature13536

Kern, S., Eichler, H., Stoeve, J., Kluter, H., and Bieback, K. (2006). Comparative analysis of mesenchymal stem cells from bone marrow, umbilical cord blood, or adipose tissue. Stem Cells 24, 1294-1301. doi: 10.1634/stemcells.2005-0342

Komori, T. (2018). Runx2, an inducer of osteoblast and chondrocyte differentiation. Histochem. Cell Biol. 149, 313-323. doi: 10.1007/s00418-018$1640-6$

Kowaltowski, A. J., and Fiskum, G. (2005). Redox mechanisms of cytoprotection by Bcl-2. Antioxid. Redox Signal. 7, 508-514. doi: 10.1089/ars.2005.7.508

Le Blanc, K., and Ringden, O. (2007). Immunomodulation by mesenchymal stem cells and clinical experience. J. Intern. Med. 262, 509-525. doi: 10.1111/j.13652796.2007.01844.x
Le Blanc, K., Rasmusson, I., Sundberg, B., Gotherstrom, C., Hassan, M., Uzunel, M., et al. (2004). Treatment of severe acute graft-versus-host disease with third party haploidentical mesenchymal stem cells. Lancet 363, 1439-1441. doi: 10.1016/s0140-6736(04)16104-7

Lee, C. H., and Kim, J. H. (2014). A review on the medicinal potentials of ginseng and ginsenosides on cardiovascular diseases. J. Ginseng Res. 38, 161-166. doi: 10.1016/j.jgr.2014.03.001

Lee, Y. J., Chung, E., Lee, K. Y., Lee, Y. H., Huh, B., and Lee, S. K. (1997). Ginsenoside-Rg1, one of the major active molecules from Panax ginseng, is a functional ligand of glucocorticoid receptor. Mol. Cell. Endocrinol. 133, 135140. doi: 10.1016/S0303-7207(97)00160-3

Lee, E. J., Ko, E., Lee, J., Rho, S., Ko, S., Shin, M. K., et al. (2004). Ginsenoside Rg1 enhances $\mathrm{CD} 4(+) \mathrm{T}$-cell activities and modulates Th1/Th2 differentiation. Int. Immunopharmacol. 4, 235-244. doi: 10.1016/j.intimp.2003.12.007

Lee, H., Kim, J., Lee, S. Y., Park, J. H., and Hwang, G. S. (2012). Processed Panax ginseng, sun ginseng, decreases oxidative damage induced by tert-butyl hydroperoxide via regulation of antioxidant enzyme and anti-apoptotic molecules in HepG2 cells. J. Ginseng Res. 36, 248-255. doi: 10.5142/ jgr.2012.36.3.248

Leung, K. W., and Wong, A. S. (2010). Pharmacology of ginsenosides: a literature review. Chin. Med. 5, 20. doi: 10.1186/1749-8546-5-20

Li, J.-W., Zhang, M.-X., Zhou, T., Torao, I., and Wang, X.-Y. (2011). Effects of ginsenoside Rg1 on the expressions of Nanog, c-Myc, Oct, Klf4, Sox2 mRNA during the differentiation of bone marrow mesenchymal stem cells into pluripotent stem cells. Chin. J. Tissue Eng. Res. 15, 6032-6035. doi: 10.3969/ j.issn.1673-8225.2011.32.032

Li, Y., Wang, Y. A., Pan, X., and Wang, B. (2013). Protective effect of ginsenoside Rg1 on MDA-induced apoptosis in mesenchymal stem cells derived from murine bone marrow. Acta Laser Biol. Sin. 22, 337-342. doi: 10.3969/ j.issn.1007-7146.2013.04.009

Li, Q., Reed, D. A., Min, L., Gopinathan, G., Li, S., Dangaria, S. J., et al. (2014). Lyophilized platelet-rich fibrin (PRF) promotes craniofacial bone regeneration through Runx2. Int. J. Mol. Sci. 15, 8509-8525. doi: 10.3390/ijms15058509

Liu, P., Xu, Y., Yin, H., Wang, J., Chen, K., and Li, Y. (2005). Developmental toxicity research of ginsenoside $\mathrm{Rb} 1$ using a whole mouse embryo culture model. Birth Defects Res. B Dev. Reprod. Toxicol. 74, 207-209. doi: 10.1002/bdrb.20038

Liu, P., Yin, H., Xu, Y., Zhang, Z., Chen, K., and Li, Y. (2006). Effects of ginsenoside Rg1 on postimplantation rat and mouse embryos cultured in vitro. Toxicol. In Vitro 20, 234-238. doi: 10.1016/j.tiv.2005.06.029

Liu, Y., Yi, L., Wang, L., Chen, L., Chen, X., and Wang, Y. (2016). Ginsenoside Rg1 protects human umbilical cord blood-derived stromal cells against tert-Butyl hydroperoxide-induced apoptosis through Akt-FoxO3a-Bim signaling pathway. Mol. Cell. Biochem. 421, 75-87. doi: 10.1007/s11010-016-2786-y

Méndez-Ferrer, S., Michurina, T. V., Ferraro, F., Mazloom, A. R., MacArthur, B. D., Lira, S. A., et al. (2010). Mesenchymal and haematopoietic stem cells form a unique bone marrow niche. Nature 466, 829-834. doi: 10.1038/nature09262

Mastrolia, I., Foppiani, E. M., Murgia, A., Candini, O., Samarelli, A. V., Grisendi, G., et al. (2019). Concise review: challenges in clinical development of mesenchymal stromal/stem cells. Stem Cells Transl. Med. 8 (11), 1135-1148. doi: 10.1002/ sctm.19-0044

Mohammed, O. J., Latif, M. L., and Pratten, M. K. (2016). Evaluation of embryotoxicity for major components of herbal extracts using the chick embryonic heart micromass and mouse D3 embryonic stem cell systems. Reprod. Toxicol. 59, 117-127. doi: 10.1016/j.reprotox.2015.12.003

Mohanan, P., Subramaniyam, S., Mathiyalagan, R., and Yang, D.-C. (2018). Molecular signaling of ginsenosides Rb1, Rg1, and Rg3 and their mode of actions. J. Ginseng Res. 42, 123-132. doi: 10.1016/j.jgr.2017.01.008

Nakatani, M., Takeyama, Y., Shibata, M., Yorozuya, M., Suzuki, H., Koba, S., et al. (2003). Mechanisms of restenosis after coronary intervention: difference between plain old balloon angioplasty and stenting. Cardiovasc. Pathol. 12, 40-48. doi: 10.1016/S1054-8807(02)00135-7

Nobuyoshi, M., Kimura, T., Ohishi, H., Horiuchi, H., Nosaka, H., Hamasaki, N., et al. (1991). Restenosis after percutaneous transluminal coronary angioplasty: pathologic observations in 20 patients. J. Am. Coll. Cardiol. 17, 433-439. doi: 10.1016/s0735-1097(10)80111-1

Ong, C. O., Chan, L. Y., Yung, P. B., and Leung, T. N. (2005). Use of traditional Chinese herbal medicine during pregnancy: a prospective survey. Acta Obstet. Gynecol. Scand. 84, 699-700. doi: 10.1111/j.0001-6349.2005.00659.x 
Ossoukhova, A., Owen, L., Savage, K., Meyer, M., Ibarra, A., Roller, M., et al. (2015). Improved working memory performance following administration of a single dose of American ginseng (Panax quinquefolius L.) to healthy middleage adults. Hum. Psychopharmacol. 30, 108-122. doi: 10.1002/hup2463

Ozaki, T., Yu, M., Yin, D., Sun, D., Zhu, Y., Bu, Y., et al. (2018). Impact of RUNX2 on drug-resistant human pancreatic cancer cells with p53 mutations. $B M C$ Cancer 18, 309. doi: 10.1186/s12885-018-4217-9

Phinney, D. G., and Pittenger, M. F. (2017). Concise review: MSC-derived exosomes for cell-free therapy. Stem Cells 35, 851-858. doi: 10.1002/stem2575

Pittenger, M. F., Mackay, A. M., Beck, S. C., Jaiswal, R. K., Douglas, R., Mosca, J. D., et al. (1999). Multilineage potential of adult human mesenchymal stem cells. Science 284, 143-147. doi: 10.1126/science.284.5411.143

Puissant, B., Barreau, C., Bourin, P., Clavel, C., Corre, J., Bousquet, C., et al. (2005). Immunomodulatory effect of human adipose tissue-derived adult stem cells: comparison with bone marrow mesenchymal stem cells. Br. J. Haematol. 129, 118-129. doi: 10.1111/j.1365-2141.2005.05409.x

Radad, K., Gille, G., Moldzio, R., Saito, H., and Rausch, W. D. (2004). Ginsenosides Rbl and Rgl effects on mesencephalic dopaminergic cells stressed with glutamate. Brain Res. 1021, 41-53. doi: 10.1016/ j.brainres.2004.06.030

Scholey, A., Ossoukhova, A., Owen, L., Ibarra, A., Pipingas, A., He, K., et al. (2010). Effects of American ginseng (Panax quinquefolius) on neurocognitive function: an acute, randomised, double-blind, placebo-controlled, crossover study. Psychopharmacol. (Berl.) 212, 345-356. doi: 10.1007/s00213-010-1964-y

Schwartz, L. M., and Osborne, B. A. (1993). Programmed cell death, apoptosis and killer genes. Immunol. Today 14, 582-590. doi: 10.1016/0167-5699(93)90197-s

Schwartz, R., Murphy, J., Edwards, W., Camrud, A., Vliestra, R., and Holmes, D. (1990). Restenosis after balloon angioplasty. A practical proliferative model in porcine coronary arteries. Circulation 82, 2190-2200. doi: 10.1161/ 01.CIR.82.62190

Shin, K., Guo, H., Cha, Y., Ban, Y. H., Seo da, W., Choi, Y., et al. (2016). Cereboost, an American ginseng extract, improves cognitive function via up-regulation of choline acetyltransferase expression and neuroprotection. Regul. Toxicol. Pharmacol. 78, 53-58. doi: 10.1016/j.yrtph.2016.04.006

Shyh-Chang, N., and Ng, H. H. (2017). The metabolic programming of stem cells. Genes Dev. 31, 336-346. doi: 10.1101/gad.293167.116

Sotaniemi, E. A., Haapakoski, E., and Rautio, A. (1995). Ginseng therapy in noninsulin-dependent diabetic patients. Diabetes Care 18, 1373-1375. doi: 10.2337/diacare.18.101373

Sun, J., Zhang, L., Zhang, J., Ran, R., Shao, Y., Li, J., et al. (2018). Protective effects of ginsenoside Rg1 on splenocytes and thymocytes in an aging rat model induced by d-galactose. Int. Immunopharmacol. 58, 94-102. doi: 10.1016/ j.intimp.2018.03.017

Takahashi, K., Tanabe, K., Ohnuki, M., Narita, M., Ichisaka, T., Tomoda, K., et al. (2007). Induction of pluripotent stem cells from adult human fibroblasts by defined factors. Cell 131, 861-872. doi: 10.1016/j.cell.2007.11.019

Tang, Y. L., Zhou, Y., Wang, Y. P., Wang, J. W., and Ding, J. C. (2015). SIRT6/NFkappaB signaling axis in ginsenoside Rg1-delayed hematopoietic stem/ progenitor cell senescence. Int. J. Clin. Exp. Pathol. 8, 5591-5596.

Tian, J., Shi, J., Wei, M., Qin, R., Ni, J., Zhang, X., et al. (2016). The efficacy and safety of Fufangdanshen tablets (Radix Salviae miltiorrhizae formula tablets) for mild to moderate vascular dementia: a study protocol for a randomized controlled trial. Trials 17, 281. doi: 10.1186/s13063-016-1410-5

Tiran, D. (2003). The use of herbs by pregnant and childbearing women: a riskbenefit assessment. Complement. Ther. Nurs. Midwifery 9, 176-181. doi: 10.1016/s1353-6117(03)00045-3

Tonino, P. A., De Bruyne, B., Pijls, N. H., Siebert, U., Ikeno, F., van' t Veer, M., et al. (2009). Fractional flow reserve versus angiography for guiding percutaneous coronary intervention. NEJM 360, 213-224. doi: 10.1056/ NEJMoa0807611

Tonna, E. A. (1960). Periosteal osteoclasts, skeletal development and ageing. Nature 185, 405-407. doi: 10.1038/185405a0

van Velthoven, C. T. J., and Rando, T. A. (2019). Stem cell quiescence: dynamism, restraint, and cellular idling. Cell Stem Cell 24, 213-225. doi: 10.1016/ j.stem.2019.01.001

von Zglinicki, T., Saretzki, G., Docke, W., and Lotze, C. (1995). Mild hyperoxia shortens telomeres and inhibits proliferation of fibroblasts: a model for senescence? Exp. Cell Res. 220, 186-193. doi: 10.1006/excr.19951305
Wagers, A. J., and Weissman, I. L. (2004). Plasticity of adult stem cells. Cell 116, 639-648. doi: 10.1016/s0092-8674(04)00208-9

Wang, P. Z., and Yaping, W. (2012). Effect of ginsenoside Rgl and recombinant bone morphogenetic protein 2 on differentiation of human dental pulp stem cells in vitro. Laser J. 33, 89-91. doi: 10.3969/j.issn.0253-2743.2012.03.045

Wang, N. Y., Lu, C. J., and Chen, X. H. (2005). Study on effect of ginsenoside Rg1 in promoting myocardiac vascular endothelial cell regeneration through induction on bone marrow stem cell's migration and differentiation in rabbits of myocardial infarction. Zhongguo Zhong Xi Yi Jie He Za Zhi 25, 916-919. doi: 10.7661/CJIM.2005.10.916

Wang, L., Wu, X., Lu, X.-Z., Ji, P., Wang, J.-H., Hou, M.-H., et al. (2007). The mechanisms of ginsenosides Rg1 on the proliferation of bone marrow stromal cells. Chin. Pharmacol. Bull. 23, 1480-1484. doi: 10.3321/j.issn:1001-1978.2007.11.019

Wang, P., Wei, X., Zhou, Y., Wang, Y. P., Yang, K., Zhang, F. J., et al. (2012). Effect of ginsenoside Rg1 on proliferation and differentiation of human dental pulp cells in vitro. Aust. Dent. J. 57, 157-165. doi: 10.1111/j.1834-7819.2012.01672.x

Wang, P., Wei, X., Zhang, F., Yang, K., Qu, C., Luo, H., et al. (2014). Ginsenoside Rg1 of Panax ginseng stimulates the proliferation, odontogenic/osteogenic differentiation and gene expression profiles of human dental pulp stem cells. Phytomedicine 21, 177-183. doi: 10.1016/j.phymed.2013.08.021

Wang, S., Zhu, R., Li, H., Li, J., Han, Q., and Zhao, R. C. (2019). Mesenchymal stem cells and immune disorders: from basic science to clinical transition. Front. Med. 13, 138-151. doi: 10.1007/s11684-018-0627-y

Wei, H. J., Yang, H. H., Chen, C. H., Lin, W. W., Chen, S. C., Lai, P. H., et al. (2007). Gelatin microspheres encapsulated with a nonpeptide angiogenic agent, ginsenoside Rg1, for intramyocardial injection in a rat model with infarcted myocardium. J. Control Release 120, 27-34. doi: 10.1016/j.jconrel.2007.04.005

Wilson, A., and Trumpp, A. (2006). Bone-marrow haematopoietic-stem-cell niches. Nat. Rev. Immunol. 6, 93-106. doi: 10.1038/nril779

Wu, W., Yang, J., Liu, B., and Wang, X. (2011). The effect of ginsenoside Rg1 on differentiation of bone marrow mesenchymal stem cells into neuron-like cells in homogenate of dementia rats. J. Apoplexy Nervous Dis. 28, 204-207. doi: CNKI:SUN:ZFSJ.0.2011-03-004

Wu, X. D., Guo, T., Liu, L., Wang, C., Zhang, K., Liu, H. Q., et al. (2017). MiR-23a targets RUNX2 and suppresses ginsenoside Rg1-induced angiogenesis in endothelial cells. Oncotarget 8, 58072-58085. doi: 10.18632/oncotarget.19489

Wyllie, A. H., Kerr, J. F., and Currie, A. R. (1980). Cell death: the significance of apoptosis. Int. Rev. Cytol. 68, 251-306. doi: 10.1016/S0074-7696(08)62312-8

Xu, S. F., Yu, L. M., Fan, Z. H., Wu, Q., Yuan, Y., Wei, Y., et al. (2012). Improvement of ginsenoside $\operatorname{Rg} 1$ on hematopoietic function in cyclophosphamide-induced myelosuppression mice. Eur. J. Pharmacol. 695, 7-12. doi: 10.1016/j.ejphar.2012.07.050

Xu, F. T., Li, H. M., Yin, Q. S., Cui, S. E., Liu, D. L., Nan, H., et al. (2014). Effect of ginsenoside $\mathrm{Rg} 1$ on proliferation and neural phenotype differentiation of human adipose-derived stem cells in vitro. Can. J. Physiol. Pharmacol. 92, 467-475. doi: 10.1139/cjpp-2013-0377

Xu, F. T., Li, H. M., Zhao, C. Y., Liang, Z. J., Huang, M. H., Li, Q., et al. (2015). Characterization of chondrogenic gene expression and cartilage phenotype differentiation in human breast adipose-derived stem cells promoted by ginsenoside Rg1 in vitro. Cell. Physiol. Biochem. 37, 1890-1902. doi: 10.1159/ 000438550

Xu, F. T., Liang, Z. J., Li, H. M., Peng, Q. L., Huang, M. H., Li, D. Q., et al. (2016). Ginsenoside Rg1 and platelet-rich fibrin enhance human breast adiposederived stem cell function for soft tissue regeneration. Oncotarget 7, 3539035403. doi: 10.18632/oncotarget 9360

Yin, L. H., Cheng, W. X., Qin, Z. S., Sun, K. M., Zhong, M., Wang, J. K., et al. (2015). Effects of ginsenoside Rg-1 on the proliferation and osteogenic differentiation of human periodontal ligament stem cells. Chin. J. Integr. Med. 21, 676-681. doi: 10.1007/s11655-014-1856-9

Zhan, S., Guo, W., Shao, Q., Fan, X., Li, Z., and Cheng, Y. (2014). A pharmacokinetic and pharmacodynamic study of drug-drug interaction between ginsenoside $\mathrm{Rg} 1$, ginsenoside $\mathrm{Rb} 1$ and schizandrin after intravenous administration to rats. J. Ethnopharmacol. 152, 333-339. doi: 10.1016/ j.jep.2014.01.014

Zheng, H. Z., Fu, X. K., Shang, J. L., Lu, R. X., Ou, Y. F., and Chen, C. L. (2018). Ginsenoside Rg1 protects rat bone marrow mesenchymal stem cells against ischemia induced apoptosis through miR-494-3p and ROCK-1. Eur. J. Pharmacol. 822, 154-167. doi: 10.1016/j.ejphar.2018.01.001 
Zhu, W., Chen, J., Cong, X., Hu, S., and Chen, X. (2006). Hypoxia and serum deprivation-induced apoptosis in mesenchymal stem cells. Stem Cells 24, 416425. doi: 10.1634/stemcells.2005-0121

Zhu, J., Mu, X., Zeng, J., Xu, C., Liu, J., Zhang, M., et al. (2014). Ginsenoside Rg1 prevents cognitive impairment and hippocampus senescence in a rat model of Dgalactose-induced aging. PloS One 9, e101291. doi: 10.1371/journal.pone.0101291

Zuo, W., Zuo, J., Zhang, Y., Zhang, Z., Wang, X., and Sun, J. (2007). The effect of ginsenoside Rg1 on differentiation of bone marrow mesenchymal stem cells into neuron-like cells. J. Apoplexy Nervous Dis. 24 (3), 282-284. doi: 10.3969/ j.issn.1003-2754.2007.03.008
Conflict of Interest: The authors declare that the research was conducted in the absence of any commercial or financial relationships that could be construed as a potential conflict of interest.

Copyright $\odot 2020 \mathrm{He}, \mathrm{Yu}$, Liu and Jia. This is an open-access article distributed under the terms of the Creative Commons Attribution License (CC BY). The use, distribution or reproduction in other forums is permitted, provided the original author(s) and the copyright owner(s) are credited and that the original publication in this journal is cited, in accordance with accepted academic practice. No use, distribution or reproduction is permitted which does not comply with these terms. 